Available online:

http://journal.imla.or.id/index.php/arabi

IMLA

Arabi : Journal of Arabic Studies, 3 (1), 2018, 70-80

DOI: http://dx.doi.org/10.24865/ajas.v3i1.70

\title{
PENGGERAKAN PROGRAM BAHASA ARAB \\ DI PONDOK PESANTREN MODERN
}

\author{
Maswan Ahmadi, Kurnia Istita'ah, Nur Rohmah Sholihah, Zakiyah Arifah \\ Universitas Islam Negeri Maulana Malik Ibrahim Malang, Indonesia \\ E-mail : ahmadimaswan@gmail.com
}

\begin{abstract}
The emergence of pesantrens that paid more attention to the Arabic language brings new hope in its development in Indonesia. Various Arabic programs are planned to improve the students' abilities in Arabic language. However, many Arabic programs do not work well because of the lack of ability to implement the program. The implementation has an important function in realizing the program that has been prepared. This implementation at least included leadership, communication, and supervision. The purpose of this research was to find an effective model of Arabic program implementation in modern boarding school. The method used was qualitative descriptive. The results showed that leadership, communication, and supervision determine whether or not the program was running.
\end{abstract}

Keywords: leadership, communication, supervision, Arabic program

\begin{abstract}
Abstrak
Munculnya pondok-pondok pesantren yang memberi perhatian yang lebih terhadap bahasa Arab membawa harapan baru dalam perkembangannnya di Indonesia. Berbagai Program Bahasa Arab dicanangkan untuk meningkatkan kemampuan santrinya dalam hal bahasa Arab. Namun demikian banyak program bahasa Arab yang tidak berjalan dengan baik karena kurangnya kemapuan dalam menggerakan program tersebut. Penggerakan mempunyai fungsi yang penting dalam mengimplementasikan progran yang telah disusun. Penggerakan ini setidaknya mencakup kepemimpinan, komunikasi, dan supervisi. Tujuan penelitian ini adalah untuk menemukan suatu model pelaksaan program bahasa Arab secara efektif di pondok pesantren modern. Metoe yang digunakan adalah kualitatif deskriptif. Hasil penelitian menunjukkan bahwa kepemimpinan, komunikasi, dan supervisi menjadi penentu berjalan tidaknya program yang canangkan.
\end{abstract}

Kata Kunci: kepemimpinan, komunikasi, supervisi, program bahasa Arab 


\section{Pendahuluan}

Penggerakan merupakan hal vital dan menjadi tanggungjawab bersama seluruh anggota lembaga. Sebuah program tidak akan terlaksana dengan baik tanpa manajemen yang bagus dan terorganisir. Proses manajemen terdiri dari empat tahapan yaitu perencanaan, pengorganisasiaan, pelaksanaan, dan pengawasan. penggerakan yang bagus dimulai dari perencanaan dan pengorganisasian yang matang. Namun perencanaan dan pengorganisasian yang bagus belum menjamin penggerakan yang bagus juga. Penggerakan merupakan inti dan implementasi sebuah rencana. Tanpa penggerakkan, maka rencana hanyalah tulisan diatas kertas dan visi misi tidak akan dapat tercapai.

Penggerakan program juga ditentukan oleh beberapa faktor yaitu: kepemimpinan (leadership), sikap dan moril (attidude and morale), tatahubungan (communication), perangsang (incentive), supervisi (supervision), dan disiplin (discipline) (Sukama, 2011). Jika syarat dari masing-masing faktor terpenuhi dengan baik, maka penggerakan berlangsung baik pula. Oleh karena itu penggerakan harus berusaha dilaksanakan dengan semaksimal mungkin agar visi misi lembaga tercapai. Namun begitu, banyak ditemui hambatan dan kegagalan di berbagai lembaga dalam aktivitas penggerakan. Hal ini disebabkan banyak faktor yang harus segera disolusikan. Oleh karena itu pengetahuan manajemen tentang seluk beluk penggerakan penting diketahui terutama oleh tim manajerial sebuah lembaga yang serius menginginkan visi misinya terwujud. Siagian (1988:128) berpendapat penggerakan atau motivating berarti "seluruh upaya pemberian motivasi kerja terhadap bawahan agar ikhlas bekerja demi terwujudnya visi misi organisasi yang efektif dan ekonomis (Azizah dan Widodo, 2014).

Model dan gaya penggerakan bahasa antar lembaga pendidikan berbeda-beda. Ini menunjukkan setiap lembaga membawa keunikan dan ciri khas masing-masing bergantung pada tujuan yang ingin dicapai. Penelitian ini memilih lembaga pendidikan Pondok Modern Darul Marifat Kediri karena kegiatan bahasanya sudah berjalan dengan baik meski para penangggungjawab silih berganti.

Pada kenyataannya program bahasa yang telah berjalan di Pondok Modern Darul Marifat Kediri laksana sebuah kereta api yang sudah berada pada rel yang benar. Siapa yang menjadi masinisnya harus dapat menjaga kereta agar selalu dapat berjalan dengan kecepatan yang ditetapkan. Apabila masinisnya lalai maka kereta akan berjalan lambat dan tidak mencapai tujuan tepat pada waktunya. Dengan adanya standar operasional yang ditetapkan oleh pimpinan pondok, maka pelaksaan program bahasa sudah memiliki rambu-rambu yang jelas dan tujuan yang dituju. Untuk mencapai hal itu maka dibutuhkan bagian yang bertanggungjawab atas terlaksananya program bahasa, dalam hal ini adalah Pembimbing Bagian bahasa (Haiah isyräf al-Lughah). Bagian memiliki seorang ketua dan beberapa anggota dalam melaksanakan fungsinya.

Berdasarkan pengamatan peneliti, pelaksaan kegiatan bahasa di Pondok Modern Darul Marifat Kediri sudah berjalan sesuai dengan yang canangkan, bahkan ada penigkatan-peningkatan, seperti, Lacinema dan hukuman kiswah. Lacinema adalah kegiatan menonton film berbahasa Arab yang diadakan di laboratorium bahasa. Hukuman kiswah adalah hukuman dengan menggunakan rompi bagi peanggar bahasa. Hal ini tidak lepas dari peran seorang ketua bagian Pembimbing bahasa dalam mengatur anggotanya untuk menggalakkan program bahasa.

Berdasar hal ini, peneliti mencoba menyoroti sisi kemampuan ketua bagian pembimbing bahasa dalam menjalankan organisasinya, khususnya dalam hal kepemimpinan, komunikasi, dan supervisi. Berdasarkan latar belakang diatas maka peneliti ingin mengetahui: 1) Bagaimana kepemimpinan ketua bagian pembimbing bahasa (Language Advisory Council) dalam menggerakkan kegiatan bahasa Arab di pondok Modern darul Ma'rifat Kediri? 2) Bagaimana komunikasi antar ketua dan anggota bagian pembimbing bahasa (LAC) dalam menggerakkan kegiatan bahasa Arab di pondok Modern darul Ma'rifat Kediri? 3) Bagaimana supervisi ketua bagian pembimbing bahasa (LAC) dalam menggerakkan kegiatan bahasa Arab di pondok Modern darul Ma'rifat Kediri? 


\section{Landasan Teori}

Penggerakan merupakan terjemahan dari bahasa Inggris yaitu actuating, di mana kata ini berasal dari bahasa Latin actuare. Handayaningrum dan Soeyono (2015:117) berpendapat bahwa penggerakan di dalam suatu organisasi adalah usaha atau tindakan dari pimpinan dalam rangka menimbulkan kemauan terhadap bawahan untuk mengetahui pekerjaannya atau tugasnya, sehingga dengan sadar menjalankan tugasnya (Tinarawati, 2017). Penggerakan ialah membangkitkan dan mendorong semua anggota kelompok agar supaya berkehendak dan berusaha dengan kertas untuk mencapai tujuan dengan ikhlas serta serasi dengan perencanaan dan usaha-usaha pengorganisasian dari pihak pimpinan (Sukama, 2011). Penggerakan juga bisa disebut dengan pengarahan, yaitu kegiatan yang dilakukan oleh pemimpin terhadap yang dipimpin, kegiatan ini berupa bimbingan, arahan, gerakan serta mengatur segala tugas yang akan diberiakan kepada para bawahan (Malayu, 2005).

Penggerakan merupakan proses pelaksanaan atau rangkaian lanjutan dari perencanaan dan pengorganisasian. Penggerakan ini berhubungan dengan orang-orang dalam kepemimpinan, dimana seorang pemimpin akan mengikat para bawahannya untuk melaksanakaan atau berusaha dengan keras mengenai tujuan yang ingin dicapai sesuai apa yang telah direncanakan diawal. Dikarenakan penggerakan merupakan rangkaian lanjutan dari perencanaan dan pengorganisasian. Oleh sebab itu, tercapainya tujuan tidak hanya dipengaruhi oleh perencanaan dan pengorganisasian yang baik saja, namun juga dipengaruhi oleh penggerakan dan pengawasan, dengan kata lain ke empat langkah ini saling mempengaruhi satu sama lain.

Namun selain dari pada itu kerjasama antara pemimpin dan bawahan juga dapat mempengaruhi tercapai atau tidaknya tujuan tersebut, karena jika antara pemimpin dan bawahan tidak memiliki kerjasama yang baik dalam melaksanakan program yang telah direncanakan maka tidak menut up kemungkinan tujuan tersebut tidak akan tercapai.

Karena penggerakan merupakan kegiatan mempengaruhi orang-orang agar bersedia mengikuti perintah yang diperintahkan, maka tindakan yang harus dilakukan oleh seorang pemimpin terhadap bawahan dalam penggerakan, yaitu memberikan motivasi, memberikan bimbingan serta arahan.

Berhasil tidaknya penggerakan melibatkan beberapa faktor, di antaranya adalah kepemimpinan (leadership), sikap dan moril (attiude and morale), tatahubungan (communication), perangsang (incentive), supervisi (supervision) dan disiplin (discipline) (Sukama, 2011). Pemakalah akan mencoba menelaah tentang hal-hal ini dengan membatasi pembahasannya dalam faktor-faktor kepemimpinan, tatahubungan, dan supervisi.

Kepemimpinan ialah kegiatan untuk mempengaruhi orang-orang agar berusaha dengan ikhlas untuk mencapai tujuan bersama (Sukama, 2011). Pemimpin pada hakikatnya adalah seseorang yang mempunyai kemampuan untuk mengarahkan dan mempengaruhi bawahan sehubungan dengan tugas-tugas yang harus dilaksanakannya (Fattah, 2017). Menurut Fahmi (2012:60), kepemimpinan merupakan proses mengarahkan, mempengaruhi, dan mengawasi orang lain untuk mengerjakan tugas sesuai dengan perintah yang direncanakan (Sariadi, 2013). Kepemimpinan merupakan faktor penggerak organisasi melalui penanganan perubahan dan manajemen yang dilakukannya sehingga keberadaan pemimpin tidak hanya sebagai simbol, akan tetapi keberadaannya juga harus dapat memberikan dampak positif bagi perkembangan organisasi (Setiawan, 2016). Kepemimpinan memberikan kontribusi yang signifikan dalam keberhasilan dan kegagalan sebuah organisasi (Puspita, 2018).

Komunikasi adalah proses penyampaian atau penerimaan pesan dari satu orang kepada orang lain, baik langsung maupun tidak langsung, secara tertulis, lisan ataupun isyarat (Usman, 2006). Argiris (1994) mendefinisikan komunikasi sebagai suatu proses dimana seseorang, kelompok, atau organisasi mengirimkan informasi (message) pada orang lain, kelompok, atau organisasi (Nurrohim dan Anatan, 2009). Komunikasi adalah proses penyampaian pesan oleh seseorang 
kepada orang lain yang pada gilirannya akan mempengaruhi pola pikir, sikap dan perilaku seseorang (Sitorus, 2006). Sedangkan komunikasi organisasi merupakan suatu proses penyampaian dan penerimaan pesan di dalam suatu organisasi dari segala arah untuk mewujudkan tujuan organisasi tersebut (Katuuk, 2016). Dalam prosesnya komunikasi setidaknya memiliki lima unsur yaitu; pengirim pesan, bahasa, pesan, penerima pesan dan respons penerima pesan. Komunikasi membantu perencanaan dan pengorganisasian managerial dilaksanakan dengan efektif, penggerakan managerial diikuti dengan efektif dan pengawasan managerial diterapkan dengan efektif (Sukama, 2011).

Kata supervisi berasal dari bahasa Inggris "supervision" yakni "super" dan "vision”. Super bermakna atas atau lebih, dan vision bermakna melihat atau meninjau (Sukatin, 2016). Pengawasan mengandung arti "suatu kegiatan pengamatan untuk melihat kerja agar selaras dengan ketentuan (Ali, 2013). Sedangkan menurut istilah, supervisi ialah kegiatan kepengurusan dalam wadah organisasi di mana pihak manajemen berhubungan dengan pihak non manajemen (Sukama, 2011). Sedangkan supervisi pendidikan ialah usaha pembimbingan dan pengarahan oleh kepala sekolah, guru senior, dan pengawas sekolah kepada guru, karyawan, dan anggota sekolah lainnya untuk meningkatkan mutu pembelajaran dan pengajaran yang efektif sehingga visi misi sekolah tercapai (Prabowo dan Yoga, 2016).

\section{Metode Penelitian}

Peneliti menggunakan metoe kualitatif deskriptif dengan subyek penelitiannya adalah ketua bagian Pembimbing bahasa di Pondok Modern Darul Ma'rifat Kediri. Data dalam penelitian ini bersumber dari dua hal, yaitu data primer dan data skunder. Data primer bersumber dari ketua pembimbing bagian bahasa, dan data skunder bersumber dari anggota bagian bahasa, ketua bagian pengasuhan santri, dan dari santri. Untuk menjamin validitas data peneliti menggunakan triangulasi sumber data. Dengan menguji data yang diperoleh dari ketua bagian pembimbing bahasa kepada atasan yang mengawasinya, yaitu bagian pengasuhan santri, dan kepada bawahannya, yaitu anggota bagian pembimbing bahasa.

Teknik pengumpulan data dilakukan dengan wawancara, observasi, dan dokumentasi. Setelah data terkumpul maka peneliti menganalisis data yang ada dengan analisis deskriptif. Data ini terkait dengan pengerakan program bahasa di Ponok Modern Darul Ma'rifat Kediri. Analisis ini berfungsi untuk mempermudah peneiti dalam memaparkan data.

\section{Hasil Penelitian}

\section{Paparan dan Analisis Data}

\begin{tabular}{|c|c|c|}
\hline No & & Data di Lapangan \\
\hline 1 & Kepemimpinan & $\begin{array}{l}\text { 1. Menurut ketua bagian pembimbing bahasa salah satu usaha yang ia } \\
\text { lakukan untuk mempengaruhi anggotanya adalah dengan menjadi } \\
\text { qudwah hasanah bagi anggotanya dalam melaksanakan tugas dan } \\
\text { menjelaskan secara detail tentang tugas yang akan ia berikan } \\
\text { kepada anggotanya. } \\
\text { 2. Ketua telah membagi tugas anggotanya dan menagih hasinya, } \\
\text { bahkan pembagian tugas harian sudah jelas dan ditempel. } \\
\text { 3. Gambaran umum kegiatan bahasa harian dimulai dari pemberian } \\
\text { mufrodat di pagi hari kepada santri oleh pengurus rayon masing- } \\
\text { masing, kemudian repeatation setalah dhuhur, pengumpulan spy } \\
\text { paper ketika sore hari, pengumuman pelanggar bahasa di masjid } \\
\text { setelah maghrib, mahkamah bahasa, pengoprasian laboratorium } \\
\text { bahasa, dan pemutaran video bahasa melalui layar TV di depan } \\
\text { gedung antara magrib dan Isya. } \\
\text { 4. Menurut Ketua bagian Pengasuhan Santri bahwa ketua bagian }\end{array}$ \\
\hline
\end{tabular}




\begin{tabular}{|c|c|c|}
\hline & & $\begin{array}{l}\text { bahasa telah membagi tugas kepada para anggotanya dan } \\
\text { mengontrol secara keseluruhan berlangsungnya kegiatan bahasa. } \\
\text { 5. Menurut anggota yang lain ketua sudah bagus dalam pembagian } \\
\text { tugas terhadap anggotanya, dan juga tegas dan istiqomah dengan } \\
\text { apa yang dikerjakan. } \\
\text { 6. Menurut ketua salah satu bentuk keseriusannya dalam } \\
\text { menggerakan program bahasa adalah dengan mendisiplinkan } \\
\text { bahasa melalui penegakkan hukuman berupa kiswah. } \\
\text { 7. Menurut salah satu anggota bagian pembimbing bahasa, ketua } \\
\text { melihat berbagai sisi dalam meningkatkan bahasa, dengan } \\
\text { memberikan tahap-tahap pendisiplinan dengan hukuman. Pertama } \\
\text { dihukum di tempat, karena dinilai tidak membuat jera, kemudian } \\
\text { ditingkatkan lagi dengan membuat insya, karena juga belum } \\
\text { memberi efek yang besar, kemudian muncullah hukuman kiswah } \\
\text { (hukuman dengan menggunakan baju berwarna-warni bagi } \\
\text { pelanggar bahasa) dan ternyata memberi efek yang baik. } \\
\text { 8. Menurut seorang santri, dengan adanya seorang pembimbing yang } \\
\text { selalu mengawasi di asrama membuatnya berbahasa Arab meski } \\
\text { ada sedikit rasa terpaksa. }\end{array}$ \\
\hline 2 & Komunikasi & $\begin{array}{l}\text { 1. Menurut angota bagian pembimbng bahasa ada agenda berupa } \\
\text { perkumpulan mingguan yang dilakukan setiap rabu malam untuk } \\
\text { melaporkan hasil pekerjaan selama satu minggu sesuai dengan } \\
\text { bagian masing-masing. } \\
\text { 2. Menurut ketua jika perintah datang secara mendadak maka } \\
\text { komunikasi dilakukan ketua langsung kepada anggota perorangan } \\
\text { sesuai dengan tugas dan fungsinya. }\end{array}$ \\
\hline 3 & Supervisi & $\begin{array}{l}\text { 1. Menurut ketua bentuk supervisi yang dia lakukan adalah dengan } \\
\text { terjun langung mengawasi mereka dilapangan, dengan tetap } \\
\text { menjaga jarak agar mereka tidak merasa terbebani, dan apabila } \\
\text { ditemukan suatu kesalahan maka akan langsung disampaikan } \\
\text { ketika itu juga sebagai evaluasi kepada yang bertanggungjawab. } \\
\text { 2. Menurut salah satu anggota bagian pembimbing bahasa ketua } \\
\text { memiliki tanggungjawab mengawasi anggotanya, di samping dia } \\
\text { juga memiliki tugas umum anggotanya, seperti mengontrol asrama } \\
\text { tertentu. } \\
\text { 3. Kendala dalam penggerakan ini adalah bahwa terkadang ada } \\
\text { beberapa anggota yang menurun semangatnya alam menjalankan } \\
\text { tugas, kemudian tidak menjalankan perintah dengn baik karena } \\
\text { salah intruksi, dan tidak paham intruksi. } \\
\text { 4. Menurut anggota bagian pembimbing bahasa, ketua sudah lumayan } \\
\text { bagus, namun beliau kadang masih lupa untuk mengerjakan } \\
\text { program yang telah ditentukan, faktor lain juga karena penanggung } \\
\text { jawab tidak melakukan dengan baik. }\end{array}$ \\
\hline
\end{tabular}

1. Kepemimpinan ketua bagian pembimbing bahasa dalam menggerakan kegiatan bahasa Arab di Pondok Modern Darul Ma'rifat Kediri

Pondok Modern Darul Ma'rifat ini terletak di desa Sumbercangkring Kecamatan Gurah Kabupaten Kediri. Pondok ini merupakan cabang ketiga dari Pondok Modern Darussalam Gontor Ponorogo. Sebagai cabang, semua pelajaran, kurikulum, dan kegiatan menginduk kepada pusat. 
Demikian halnya dengan kegiatan bahasa, meski dalam pelaksanaannya berbeda, namun inti dan nilai sudah sesuai dengan pusat.

Salah satu bagian yang bertanggungjawab dalam kegiatan bahasa adalah bagian pembimbing bahasa. Bagian ini menjadi inti gerakan bahasa. Bagian ini memiliki struktur organisasi. Dengan seorang ketua (pemimpin) yang bertanggungjawab penuh. Dalam kapasitas sebagai pemimpin ketua memiliki tugas untuk dapat membagi tugas kepada anggotanya. Sebagaimana pengertian Kepemimpinan yang telah disebutkan sebagai kegiatan untuk mempengaruhi orang-orang agar berusaha dengan ikhlas untuk mencapai tujuan bersama. Pemimpin pada hakikatnya adalah seseorang yang mempunyai kemampuan untuk mengarahkan dan mempengaruhi bawahan sehubungan dengan tugas-tugas yang harus dilaksanakannya. Ketua memiliki tugas untuk dapat mempengaruhi anggotanya agar dapat melaksanakan tugas dengan baik. Menurut ketua bagian pembimbing bahasa salah satu usaha yang ia lakukan untuk mempengaruhi anggotanya adalah dengan menjadi qudwah hasanah bagi anggotanya dalam melaksanakan tugas dan menjelaskan secara detail tentang tugas yang akan ia berikan kepada anggotanya (Jubaidah, 2015).

\begin{tabular}{|c|c|c|c|}
\hline No & Nama & Jabatan & Tugas \\
\hline 1 & Zulfikar & Ketua & $\begin{array}{l}\text { Umum, CLI, Asrama Sudan } 2 \text { dan } \\
\text { Asrama Palestina }\end{array}$ \\
\hline 2 & A faizin $\mathrm{S}$ & Wakil Ketua & $\begin{array}{l}\text { Lacinema, CLM, Asrama Makkah } 1 \text { dan } \\
\text { Makkah } 2\end{array}$ \\
\hline 3 & M Alex S & Sekretaris & Silabus, CLM, Asrama Al-Azhar \\
\hline 4 & $\begin{array}{l}\text { Didin } \\
\text { Manca }\end{array}$ & Bendahara & $\begin{array}{l}\text { Pengadilan Bahasa, Kelas } 5 \text { dan 6, } \\
\text { Asrama Santiniketan dan Asrama Sudan }\end{array}$ \\
\hline 5 & Abdurrahman & Bendahara & Kegiatan Jum'at, CLI, Asrama Syanggit \\
\hline 6 & Zaki Alawi & $\begin{array}{l}\text { Perlengkapa } \\
\mathrm{n}\end{array}$ & $\begin{array}{l}\text { Pertunjukan Bahasa, LCD, Asrama } \\
\text { Makkah } 3\end{array}$ \\
\hline 7 & Wan Muslim & Sekretaris & Lacinema, LCD, Asrama Mesir \\
\hline 8 & A Muchtar & $\begin{array}{l}\text { Perlengkapa } \\
\mathrm{n}\end{array}$ & $\begin{array}{l}\text { Pengadilan Bahasa, Kelas } 5 \text { dan } 6 \text {, } \\
\text { Asrama Aligarh }\end{array}$ \\
\hline
\end{tabular}

Tabel Distribusi Tugas

\section{Keterangan:}

- CLI (Central Language Improvement) adalah organisasi bahasa oleh para santri dan berada dibawah LAC

- CLM (Chief Language Motivator)/ ketua bagian bahasa di asrama

Secara umum kegiatan bahasa meliputi harian, mingguan, bulanan dan tahunan. Gambaran umum kegiatan bahasa harian dimulai dari pemberian mufrodat di pagi hari kepada santri oleh pengurus rayon masing-masing, kemudian repeatation setalah dhuhur, pengumpulan spy paper ketika sore hari, pengumuman pelanggar bahasa di masjid setelah magrib, mahkamah bahasa, pengoprasian laboratorium bahasa, dan pemutaran video bahasa melalui layar TV di depan gedung antara Maghrib dan Isya'. Semua program ini dapat berjalan dengan pembagian tugas yang detail.

Menurut salah satu anggota bagian pembimbing bahasa, ketua telah membagi tugas anggotanya dan menagih hasinya, bahkan pembagian tugas harian sudah jelas dan ditempel. Menurut Ketua bagian Pengasuhan Santri bahwa ketua bagian bahasa telah membagi tugas kepada para anggotanya dan mengontrol secara keseluruhan berlangsungnya kegiatan bahasa. Senada dengan ini, menurut anggota yang lain ketua sudah bagus dalam pembagian tugas terhadap anggotanya, dan juga tegas dan istiqomah dengan apa yang dikerjakan. Dengan pengaruh berupa qudwah hasanah yang dimiliki ketua bagian pembimbing bahasa serta intruksi pembagian tugas yang detail kegiatan bahasa ini dapat berjalan dengan baik.

Salah satu bentuk keseriusan ketua dalam menggerakan program bahasa adalah dengan mendisiplinkan bahasa melalui penegakkan hukuman berupa kiswah. Menurut salah satu anggota bagian pembimbing bahasa, ketua melihat berbagai sisi dalam meningkatkan bahasa, dengan 


\section{Arabi : Journal of Arabic Studies}

memberikan tahap-tahap pendisiplinan dengan hukuman. Pertama dihukum di tempat, karena dinilai tidak membuat jera, kemudian ditingkatkan lagi dengan membuat insya, karena juga belum memberi efek yang besar, kemudian muncullah hukuman kiswah (hukuman dengan menggunakan baju berwarna-warni bagi pelanggar bahasa) dan ternyata memberi efek yang baik.

Menurut salah satu santri peraturan disiplin bahasa ini sudah bagus dan memberinya dorongan untuk berbahasa, meski dengan terpaksa. Ia sudah mulai berdialog dengan temannya dengan menggunakan bahasa Arab, meski masih sangat sedikit. Ia pun sering masuk daftar Mahkamah al-Lughah (pengadilan bahasa) karena melanggar bahasa, namun ini ada proses untuk berbahasa. Sedang menurut santri lain, dengan adanya seorang pembimbing yang selalu mengawasi di asrama membuatnya berbahasa meski ada sedikit rasa terpaksa. Sehingga ia tak berani untuk berbahasa Indonesia, bahkan kepada temannya.

2. Komunikasi antarketua dan anggota bagian pembimbing bahasa dalam menggerakan kegiatan bahasa Arab di Pondok Modern Darul Ma'rifat Kediri

Telah dijelaskan bahwa komunikasi memegang peran penting dalam suatu organisasi. Kegiatan seperti pengorganisasian itu sendiri, penggerakan dan pengawasan berhasil atau tidaknya tergantung pada komunikasi karena jika tidak ada komunikasi antara atasan dan bawahan proses manajemen tidak akan berjalan dengan baik. Maka pada pelaksanaan program bahasa di Pondok Modern Daru Ma'rifat proses komunikasi terjadi antara ketua dan anggota setiap harinya. Namun untuk meningkatkan komunikasi, maka dilakukan komunikasi intern satu kali dalam seminggu, dengan tujuan agar dapat mengevaluasi, memberi masukan dan merencanakan program-program baru, atau untuk menyampaikan suatu perintah dan pembagiannya. Perkumpulan mingguan ini dilakukan setiap rabu malam untuk melaporkan hasil pekerjaan selama satu minggu sesuai dengan bagian masing-masing. Namun jika perintah datang secara mendadak maka komunikasi dilakukan ketua langsung kepada anggota perorangan sesuai dengan tugas dan fungsinya, atau yang disebut komunikasi informil.

Komunikasi yang rutin ini telah menciptakan suasana perubahan sosial, maing-masing anggota menganggap penting diri dan tugasnya. Sehinga timbul istilah "kalau tidak ada saya, maka program ini tidak berjalan". Slogan ini semata-mata hanya untuk menumbuhkan sikap tanggungjawab dan menganggap penting tugas dan petugas tersebut. Tidak lebih.

3. Supervisi ketua bagian pembimbing bahasa dalam menggerakan kegiatan bahasa Arab di

Pondok Modern Darul Ma'rifat Kediri

Meski telah dibagi tugas, seorang pemimpin tetap harus mengawasi anggotanya ketika melaksanakan tugasnya masing-masing. Supervisi juga merupakan bentuk suatu hubungan antara ketua dan anggotanya. Fungsinya untuk menggerakan anggota dan memberi semagat kepada mereka. Bentuk supervisi yang dilakukan oleh ketua bagian pembimbing bahasa adalah dengan terjun langung mengawasi mereka dilapangan, dengan tetap menjaga jarak agar mereka tidak merasa terbebani, dan apabila ditemukan suatu kesalahan maka akan langsung disampaikan ketika itu juga sebagai evaluasi kepada yang bertanggungjawab. Hal ini dimaksudkan untuk mencari-cari kesalahan. Namun untuk mengawal agar program yang telah dijalankan sesuai dengan tujuan. Menurut salah satu anggota bagian pembimbing bahasa ketua memiliki tanggungjawab mengawasi anggotanya, disamping dia juga memiliki tugas umum anggotanya, seperti mengontrol asrama tertentu.

Dengan demikian setiap program bahasa dapat digerakkan sesuai dengan tujuan. Karena setiap kegiatan dan program memiliki tujuan masing-masing yang harus dicapai. Sebagai fungsi utama supervisi yang dilakukan oleh ketuan pembimbing bahasa tidak membatasi mereka dalam berkreasi atau mencari-cari kesalahan, namun untuk memastikan bahwa program yang sedang dilakukan dapat mencapai tujuan dengan baik.

Sedang kendala dalam penggerakan ini adalah bahwa terkadang ada beberapa anggota yang menurun semangatnya alam menjalankan tugas, kemudian tidak menjalankan perintah dengn baik karena salah intruksi, dan tidak paham instruksi. Ketua sudah lumayan bagus, namun beliau 
kadang masih lupa untuk mengerjakan program yang telah ditentukan, faktor lain juga karena penanggungjawab tidak melakukan dengan baik. Dengan adanya supervisi dapat menambal kekurangan-kekurangan ini dalam pelaksanaannya di lapangan.

\section{Pembahasan}

1. Kepemimpinan ketua bagian pembimbing bahasa dalam menggerakan kegiatan bahasa Arab di Pondok Modern Darul Ma'rifat Kediri

Kepemimpinan ketua bagian pembimbing bahasa menitik beratkan pada dua titik, yaitu, pertama, menjadi qudwah hasanah atau menjadi contoh yang baik bagi anggotanya dalam menjalankan tugasnya. Dan kedua, memberikan instruksi yang detail kepada para anggotanya. Dalam hal ini, sikap seperti sudah memenuhi definisi kepemimpinan menurut Sukarna (2011). Ia menyatakan bahwa Kepemimpinan ialah kegiatan untuk mempengaruhi orang-orang agar berusaha dengan ikhlas untuk mencapai tujuan bersama.

Dengan memberikan contoh yang baik dalam menjalankan tugas, maka akan menimbulkan sikap rela untuk menjalankan tugas. Karena perbuatan akan lebih mempenaruhi jiwa seseorang daripada hanya sekedar ucapan. Sedang dengan penjelasan detail tentang tugas akan lebih mendekatkan kepada pencapaian tujuan suatu program. Sedang tipe kepemimpinannya sesuai yang G.R Terry sebutkan dalam Sukama (2011) termasuk:

1) Kepemimpinan pribadi, karena ia mengadakan hubungan langsung dengan bawahannya sehingga timbul hubungan pribadi yang intim.

2) Kepemimpinan demokratis, karena ia selalu mengadakan musyawarah dengan para bawahannya untuk menyelesaikan pekerjaan-pekerjaan yang sukar sehingga para bawahan akan merasa dihargai pemikiran-pemikirannya dan pendapat- pendapatnya serta memiliki pengalaman yang baik di dalam menghadapi segala persoalan yang rumit.

3) Kepemimpinan bakat, karena ia dapat menggerakan bawahannya dengan memiliki bakat untuk itu menyebabkan para bawahan senang mengikutinya.

Dari tiga penekatan kepemimpinan, ketua bagian bahasa ini termasuk dalam pendekatan perilaku. Pendekatan ini memandang bahwa kepemimpinan dapat dipelajari dari pola tingkah laku, dan bukan dari sifat-sifat pemimpin. Alasannya sifat seseorang relatif sukar untuk diidentifikasikan. James Owen, berkeyakinan bahwa perilaku dapat dipelajari, hal ini berarti bahwa orang yang dilatih dalam perilaku kepemimpinan yang tepat akan dapat memimpin secara efektif. Perilaku ketua bagian pembimbing dengan mengedepankan qudwah hasanah bagi anggotanya menunjuukan perilaku dapat mempengaruhi seseorang. Sedang efektivitas kepemimpinan seperti ini sudah cukup baik. Meski masih didapati kekurangan, seperti hilangnya semangat anggotanya pada suatu waktu, dan kesalahan anggota dalam memahami intruksi dari ketua.

2. Komunikasi antar ketua dan anggota bagian pembimbing bahasa dalam menggerakan kegiatan bahasa Arab di Pondok Modern Darul Ma'rifat Kediri

Pola komunikasi dalam organisasi pembimbing bahasa dilakukan secara lisan oleh ketua kepada para anggota, dengan mengadakan kumpul setiap minggunya. Dalam pertemuan tersebut proses komunikasi sangat dominan. Proses penyampaian atau penerimaan pesan dari satu orang kepada orang lain terjadi secara langsung dan mendapat respon langsung. Pesan tersebut dapat berupa intruksi, evaluasi, dan program kedepan.

Proses komunikasi ini telah memenuhi unsur-unsur komunikasi berupa pengirim pesan, bahasa, pesan, penerima pesan dan respons penerima pesan. menurut peneliti komunikasi yang dilakukan oleh bagian pembimbing bahasa mencakup:

1) komunikasi internal, komunikasi yang dilakukan dalam organisasi itu sendiri baik antara atasan dengan atasan atau bawahan dengan bawahan atau antara atasan dan bawahan atau sebaliknya. Terbukti dengan adanya kumpul di setiap minggunya. 


\section{Arabi : Journal of Arabic Studies}

2) komunikasi vertikal, komunikasi yang dilakukan dalam intern organisasi antara atasan dan bawahan atau sebliknya dalam suasana formil. Ini terbukti dengan adanya penyampaian intruksi dari ketua ke anggota dan adanya respon dari anggota ke ketua.

3) komunikasi formal, komunikasi yang dilakukan baik intern maupun ekstern secara formil. Terbukti dengan kumpul setiap minggunya.

4) komunikasi informal, komunikasi yang dilakukan baik intern maupun ekstern secara informil artinya secara pribadi. Terbukti dengan aanya intruksi mendadak yang langsung disampaikan ketua kepada anggotanya sesuai tugasnya.

5) komunikasi lisan. komunikasi yang dilakukan secara lisan baik intern maupun ekstern, formil maupun informil atau vertikal maupun horizontal. Terbukti seringnya terjadi intruksi berupa penyampaian secara langsung. Hal ini juga didukung faktor lain. Seperti sering bertemunya ketua dengan anggota, sehingga tidak memerlukan media tulisan.

Dengan komunikasi seperti ini, penggerakan bahasa berjalan dengan baik. Karena dalam komunikasi tersebut sudah tergambar tentang sikap ketua dalam berkomunikasi yang baik terhadap anggotanya. Meski demikian agar tidak terjadi kesalahan pemahaman yang disebabkan komunikasi, maka harus tetap dilakukan komunikasi tulisan supaya membantu anggota dalam mengingat instruksi yang di berikan kepadanya.

3. Supervisi ketua bagian pembimbing bahasa dalam menggerakan kegiatan bahasa Arab di Pondok Modern Darul Ma'rifat Kediri

Bentuk supervisi yang dilakukan ketua bagian pembimbing bahasa adalah dengan terjun langsung kelapangan mengawasi kegiatan yang sedang berangsung, dengan tetap menjaga jarak agar anggota yang sedang menjalankan tugas tidak merasa terbatasi geraknya, apabila ditemukan suatu kesalahan, maka evaluasi langsung diberikan di lapangan.

Merujuk kepada makna supervisi yang merupakan salah satu strategi untuk memastikan bahwa seluruh langkah pada proses penyelenggaraan dan semua komponen hasil yang dicapai memenuhi target. Juga kegiatan supervisi bukan mencari-cari kesalahan tetapi lebih banyak mengandung unsur pembinaan, agar kondisi pekerjaan yang sedang disupervisi dapat diketahui kekurangannya (bukan semata-mata kesalahannya) untuk dapat diberitahu bagian yang perlu diperbaiki. Apa yang telah dilakukan oleh ketua bagian pembimbing bahasa, sudah mewakili pengertian supervisi di atas.

Dari empat model supervisi, yaitu: model supervisi konvensional (tradisional), Model supervisi ilmiah, Model supervisi klinis, dan Model supervisi artistic. Ketua bagian pembimbing bahasa lebih dekat kepada model supervisi ilmiah. Supervisi ini memiliki ciri-ciri, diantaranya: dilaksanakan secara berencana dan kontinu, sistematis, dan menggunakan prosedur serta teknik tertentu, menggunakan instrumen pengumpulan data dimana data tersebut obyektif yang diperoleh dari keadaan yang riil. Hal ini sesuai dengan apa yang dilakukan ketua untuk terjun langsung mengawasi dilapangan, sehingga data yang diperoleh lebih riil.

Jika dinalai dari sudut efektifnya, supervisi ini sudah termasuk efektif, karena telah sesuai dengan beberapa ciri-ciri TQC yang efektif di antaranya (Fattah, 2006):

1) Pengawasan atau supervisi harus dikaitkan dengan tujuan, dan kriteria yang dipergunakan dalam sistem pendidikan, yaitu relevansi, efektivitas, efisiensi, dan produktivitas. Terbukti dengan berjalannya program bahasa dengan baik.

2) Pengawasan hendaknya disesuaikan dengan sifat dan kebutuhan organisasi. Saat ini apa yang telah dilakukan ketua bagian pembimbing bahasa suah memenuhi kebutuhan tersebut.

3) Banyaknya pengawasan harus dibatasi. Artinya, jika pengawasan teradap karyawan terlampau sering, ada kecenderungan mereka kehilangan otonominya dan dapat dipersepsi pengawasan itu sebagai pengekangan. Terbukti dengan supervisi yang dilakukan hanya mengawasi dari kejauhan agar tidak mengekang anggota. 
4) Pengawasan hendaknya mengacu pada tindakan perbaikan, artinya tidak hanya mengungkap penyimpangan dari standar, tetapi penyediaan alternatif perbaikan, menentukan tindakan perbaikan. Terbukti dengan diberikan langsung evaluasi dilapangan jika terdapat kesalahan.

Pengawasan hendaknya mengacu pada prosedur pemecahan masalah, yaitu: menemukan masalah, menemukan penyebab, membuat rancangan penaggulangan, melakukan perbaikan, mengecek hasil perbaikan, mencegah timbulnya masalah yang serupa. Evaluasi langsung dilapangan memudahkan memecahkan masalah.

\section{Simpulan}

Penggerakan Program bahasa oleh ketua bagian pembimbing bahasa di Pondok modern Darul Ma'rifat Kediri sudah memenuhi sebagaian dari sistem penggerakan, seperti kepemimpinan, komunikasi, dan supervisi. Pertama, Kepemimpinan ketua bagian pembimbing bahasa telah sesuai dengan defenisi kepemimpinan oleh Sukarna yang intinya dapat mempengaruhi anggotanya untuk dapat bekerja dengan ikhlas dalam upaya mencapai tujuan bersama. Hal ini diwujudkan dengan adanya qudwah hasanah. Hal ini kemudian mempengaruhi anggotanya. Ia termasuk kedalam katagori kepemimpinan pribadi, demokratis, dan bakat. Sedang efektifitas kepemimpinan seperti ini sudah cukup baik. Meski masih didapati kekurangan, seperti hilangnya semangat anggotanya pada suatu waktu. Kedua, komunikasi antara ketua dan anggotanya sudah berjalan dengan cukup baik. Dengan adanya wadah berkumpul sekali dalam seminggu, menjadikan komunikasi menjadi lebih baik. karena Proses penyampaian atau penerimaan pesan dari satu orang kepada orang lain terjadi secara langsung dan mendapat respon langsung. Pesan tersebut dapat berupa intruksi, evaluasi, dan program kedepan. Komunikasi tersebut berupa komunikasi intern, vertiakal, formil, informil, dan lisan. Meski masih didapati kendala berupa kesalahan anggota dalam memahami intruksi dari ketua. Ketiga, Supervisi yang dilakukan dengan mengawasi anggota ddari jauh gna memberi ruang gerak lebih dan tidak mengekang, dan evaluasi secara langung dilapangan menggambarkan salah datu ciri-ciri pengawasan yang efektif. Sesuai dengan tujuan supervisi agar dapat mencapai tujuan yang di inginkan maka supervisi yang dilakukan sudah dapat menjaga usaha dari kesalahan-kesalahan sehingga tujuan tidak dapat dicapai.[]

\section{Daftar Rujukan}

Ali, St hasniyati Gani. 2013. "Implementasi Profesionalisme Pengawas Dalam Meningkatkan Kreativitas Guru Pendidikan Agama Islam Pada Madrasah Aliyah Negeri Di Provinsi Sulawesi Tenggara". Al-Izzah, Vol. 8, No. 1.

Azizah, Imroatul. dan Bambang Sigit Widodo. 2014. "Manajemen Layanan Perpustakaan Sekolah”, Jurnal Inspirasi Manajemen Pendidikan, Vol. 4 No. 4.

Fattah, Nanang. 2017. Landasan Manajemen Pendidikan, Cet 14, Bandung: Rosdakarya

Jubaidah, Siti. 2015. "Pembelajaran dan Pemerolehan Bahasa Arab di Pondok Modern Gontor di Darul Ma'rifat Gurah Kediri Jatim”, Jurnal Parameter, Vol. 27, No. 2.

Katuuk, Oktaviani Margareta. dkk. 2016 "Peran Komunikasi Organisasi Dalam Meningkatkan Eksistensi Sanggar Seni Vox Angelica”, e-journal Acta Diurna, Vol. V. No. 5.

Malayu. 2005. Manajemen Dasar, Pengertian dan Masalah, Cet 4, Jakarta: Bumi Askara

Nurrohim, Hassa. dan Lina Anatan. 2009. "Efektivitas Komunikasi Dalam Organisasi”, Jurnal Manajemen, Vol.7, No.4.

Prabowo, Suto. Dyah Satya Yoga. 2016. "Supervisi Kunjungan Kelas sebagai Upaya Membina Profesional Guru SLTP/SLTA”, Jurnal Sosial humaniora, Vol. 9, No. 1.

Sariadi, Sarly. 2013. "gaya Kepemimpinan dan Motivasi Pengaruhnya Terhadap Kinerja Pegawai Pada Bagian Sekretriat TNI AL LANTAMAL VIII Di Manado”, Jurnal EMBA, Vol. 1 No. 4. 
Arabi : Journal of Arabic Studies

Setiawan, Awang. 2016. "Kontribusi Kepemimpinan Transformasional Kepala Sekolah dan Iklim Sekolah Terhadap Efektivitas Sekolah", Jurnal Administrasi Pendidikan, Vol. XXIII, No. 1.

Sitorus, Monang. 2006. "Pengaruh Komunikasi Dan Kepemimpinan Terhadap Efektivitas Penerimaan Pajak Reklame (Studi Pada Dinas Pendapatan Daerah Kota Bandung)”, Jurnal VISI, Vol. 5, No. 1.

Sukarna. 2011. Dasar-Dasar Manajemen, Cet 2, Bandung: Mandar Maju.

Sukatin. 2016. "Manajemen Supervisi dalam Pendidikan", Hikmah: Jurnal Pendidikan Islam, Vol 5, No. 2.

Tinarawati, Selfi. 2017. "Penerapan Fungsi Manajemen Pada Komunitas Paduan Suara Surabaya Singer Dalam Rangka Kompetisi Singapore International Choir Festival 2017”, diakses dari http://jurnalmahasiswa.unesa.ac.id

Usman, Husaini. 2006. Manajemen, Jakarta: Bumi Askara. 